\title{
Biogeographic and Taxonomic Contributions to the Genus Sorbus L. (Rosaceae) in Turkey: Sorbus buschiana and Sorbus luristanica
}

\author{
Türkiye'deki Sorbus L. (Rosaceae) Cinsine Biyocoğrafik ve \\ Taksonomik Katkılar: Sorbus buschiana ve Sorbus luristanica
}

Research Article

Ali A. Dönmez* and Zübeyde Uğurlu Aydın

Department of Biology, Faculty of Science, Hacettepe University, Beytepe, Ankara, Turkey.

\section{A B S TRACT}

Secimens of Sorbus buschiana Zinserl. were collected from Çankırı and Rize and given here as a new record $\checkmark$ for the Turkish Flora. Detailed description, distribution map and phenological observations are also provided here. The new record is assigned to VU category according to IUCN. Based on all of the common knowledge mostly accepted and well known literature, S. Iuristanica naturally grows in Turkey and this is currently accepted idea about the species. Opposing to the common acceptation, recent studies both in herbaria and field works in Turkey explained that the species doesn't grow in Turkey. This paper also acknowledges the current situation of S. luristanica based on literature, herbarium and field studies.

\section{Key Words}

Flora, New record, Sorbus, Turkey.

\section{öz}

\begin{abstract}
Sorbus buschiana Zinserl. Çankırı ve Rize illerinden toplanmış ve Türkiye Florası için yeni kayıt olduğu bu çalışmada açıklanmıştır. Bu türün ayrıntılı betimi, yayılış örüntüsü ve fenolojik gözlemleri verilmiştir. Yeni kayıt IUCN standartlarına göre VU tehlike kategorisine yerleştirilmiştir. En çok kabul gören ve son literatür bilgilerine göre, Sorbus Iuristanica'nın Türkiye'de doğal olarak yetiştiği belirtilmekte ve bu bilgi halen kabul edilmektedir. Bilinenlerin tersine, hem herbaryumlarda hem de arazide yapılan çalışmaları ile bu türün Türkiye'de yetişmediği tespit edilmiştir.
\end{abstract}

\section{Anahtar Kelimeler}

Flora, Sorbus, Türkiye, Yeni kayıt.

Article History: Received: Mar 16, 2017; Revised: Aug 10, 2017; Accepted: Oct 4, 2017; Available Online: Dec 25, 2017 DOI: 10.15671/HJBC.2018.174

Correspondence to: A. Dönmez, Department of Biology, Faculty of Science, Hacettepe University, Beytepe, Ankara, Turkey. 


\section{INTRODUCTION}

The he genus Sorbus L. s.l. in Turkey is fairly known from the Turkish Flora [1], database [2] and the other literatures [3,4]. Recently published synopsis [5] mostly followed the mentioned database. Because of the taxonomic intricacy $[6,7]$ both of species delimitation and distribution pattern of them, alongside of the Caucasian taxa, all of the Turkish taxa of the genus has been studied [8]. By the taxonomic revision of the genus Sorbus, correct distribution patterns of the S. buschiana and S. Iuristanica are explained in this paper.

\section{MATERIALS and METHODS}

The specimens of Sorbus buschiana were from Çankırı and Rize during the field trips between 2013-2014 in both flowering and fruiting materials by the first author. The specimens were identified using the Flora URSS [3] and the other relevant literature $[1,4,9]$ and herbarium specimens at $E_{\text {, }}$ $G E, K, L E, S, T B I$ and UPS have been studied by visiting or electronically. The collected herbarium specimens are kept in Hacettepe University Herbarium (HUB).

\section{RESULTS and DISCUSSION}

Sorbus buschiana Zinserl.; FI. URSS ix. 392, 495. 1939. Figure 1.

Type: Delvars, inter pagos N. Ermani et Schavlochovo, in schistosis, alt. 1850-2200 m legerunt E. et N. Busch (lectotype: LE!, isolectotype: TBI!).

Trees up to 3-4 $\mathrm{m}$ or shrub, crown globose. Stem bark dark grey. Young branches brown, sparsely lanate, later glabrous with numerous elliptic lenticels. Buds ovate, oblong, 8-10 x 5-7 $\mathrm{mm}$, scales brown, ovate, glabrous, irregularly lobed, sparsely hairy, scarious at margin with long mucro at apex, sticky. Leaves rounded, rarely ovate, (8-)9-12 x (8-)9-12 cm, shiny, glabrous or sparsely hairy at above, glabrous in fruit; pale greyish-green, lanate at below; shortly cuneate or rounded at base; rounded at apex with small mucro, irregularly fine toothed at margin, with shallowly secondary lobs, with 9-10 pair veins; petioles 8-10 $\mathrm{mm}$, sparsely hairy. Stipules triangular-lanceolate, 4-7 mm, sparsely lanate, deciduous. Inflorescence a corymb with (20-)25-30(-45) flowers, 8-10(-13) $\mathrm{cm}$ in diameter; inflorescence axis and pedicels sparsely lanate; baracts subulate, 6-8 $\mathrm{mm}$, sparsely hairy, deciduous; bracteoles similar to bracts, smaller. Flowers $10-15 \mathrm{~mm}$ in diameter. Hypanthium campanulate, sparsely lanate at outer, glabrous in fruit. Sepals spreading, 2-2.5 x 2-2.5 $\mathrm{mm}$, triangular, acute at apex, sparsely hairy on both side, persistent at fruit. Petals white, elliptic or rounded, 4-6 x 4-6 mm, concave without claw, sparsely hairy at base. Stamens 20 , unequal. Ovary perigyn, densely lanate at above; styles 2 , lanate at base. Fruits (8-)9-12 x 8-10 mm, dark red, ovateglobose, with numerous lenticel, (10)15-20(-30) each infrutescence. Seeds 4(-6), 2 per loculi, 5-7 $x$ 3-4 mm, brown, triangular. Chromosomes: $2 \mathrm{n}=68$.

\section{Material Examined}

Turkey, Çankırı: from Kurşunlu to Bayramören, around Melan village, mixed forest with QuercusPinus sp., $1390 \mathrm{~m}, 40^{\circ} 56^{\prime} 36.5^{\prime \prime} \mathrm{N}, 033^{\circ} 18^{\prime} 18.5^{\prime \prime} \mathrm{E}$, 30 May 2014, A.A. Dönmez 19029 (HUB); ibid. 19 September 2014, A.A. Dönmez 19192 (HUB); ibid. A.A. Dönmez 19193 (HUB); ibid. A.A. Dönmez 19195 (HUB); Rize: Çamlıhemşin, Sıraköy, 1903 m, 4048'26.5"N, 04055'70.3"E, 2 June 2013, A.A. Dönmez 18557 (HUB).

\section{Habitat}

Grows on open area composed of deciduous forest and among Quercus spp. scrub at altitudes of 800-1900 m.

\section{Threatened Category (IUCN, 2016)}

Specimens of S. buschiana was collected from two different places in Turkey. Regarding distances, these localities are very far away from each other. However, the population density of the species in these two locality are not rich. Beside this, due to the hard field conditions we could not conduct extensive field research in the areas. Both of these habitats have considerable threats to the populations. On the other hand, because of fruit distribution by birds and mammals it is possible to find another members of the species at another location. Therefore, the species are assigned to Vulnerable (VU) B1a+B2a category based on IUCN [10]. 


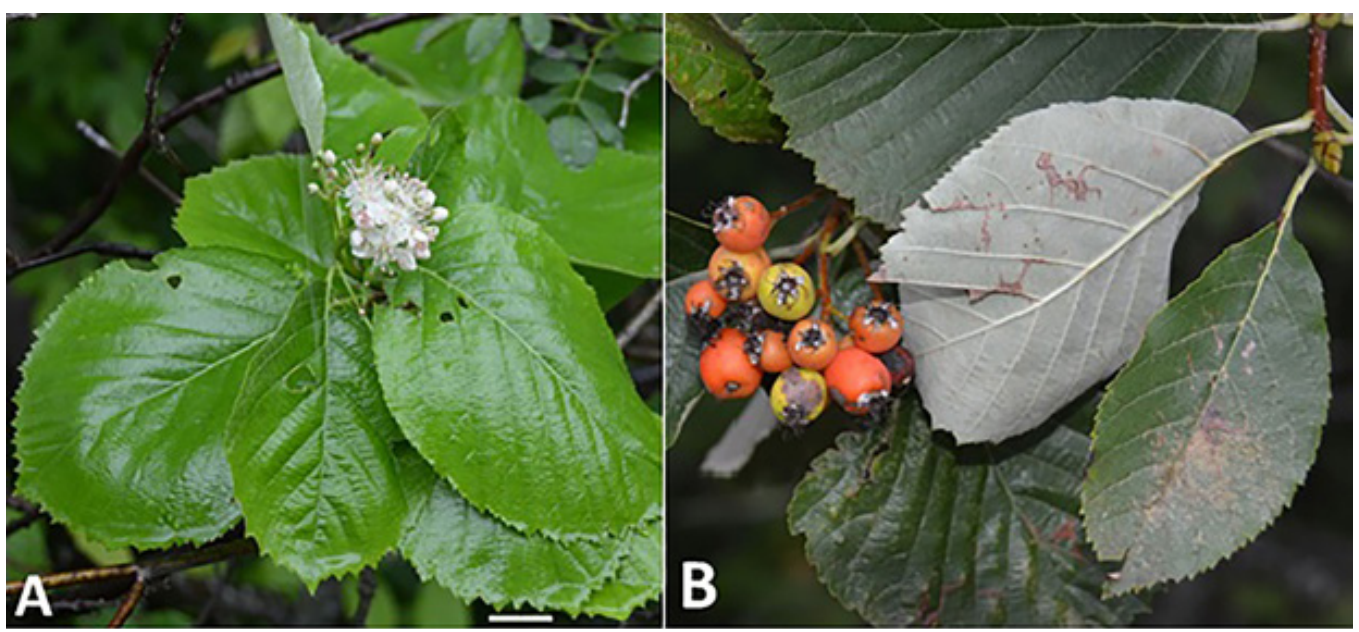

Figure 1. Sorbus buschiana. Flowering branches (A- from AAD 19029), fruiting branches (B- from AAD 19193) (Photos by Dönmez; scale bar $=1 \mathrm{~cm}$ ).

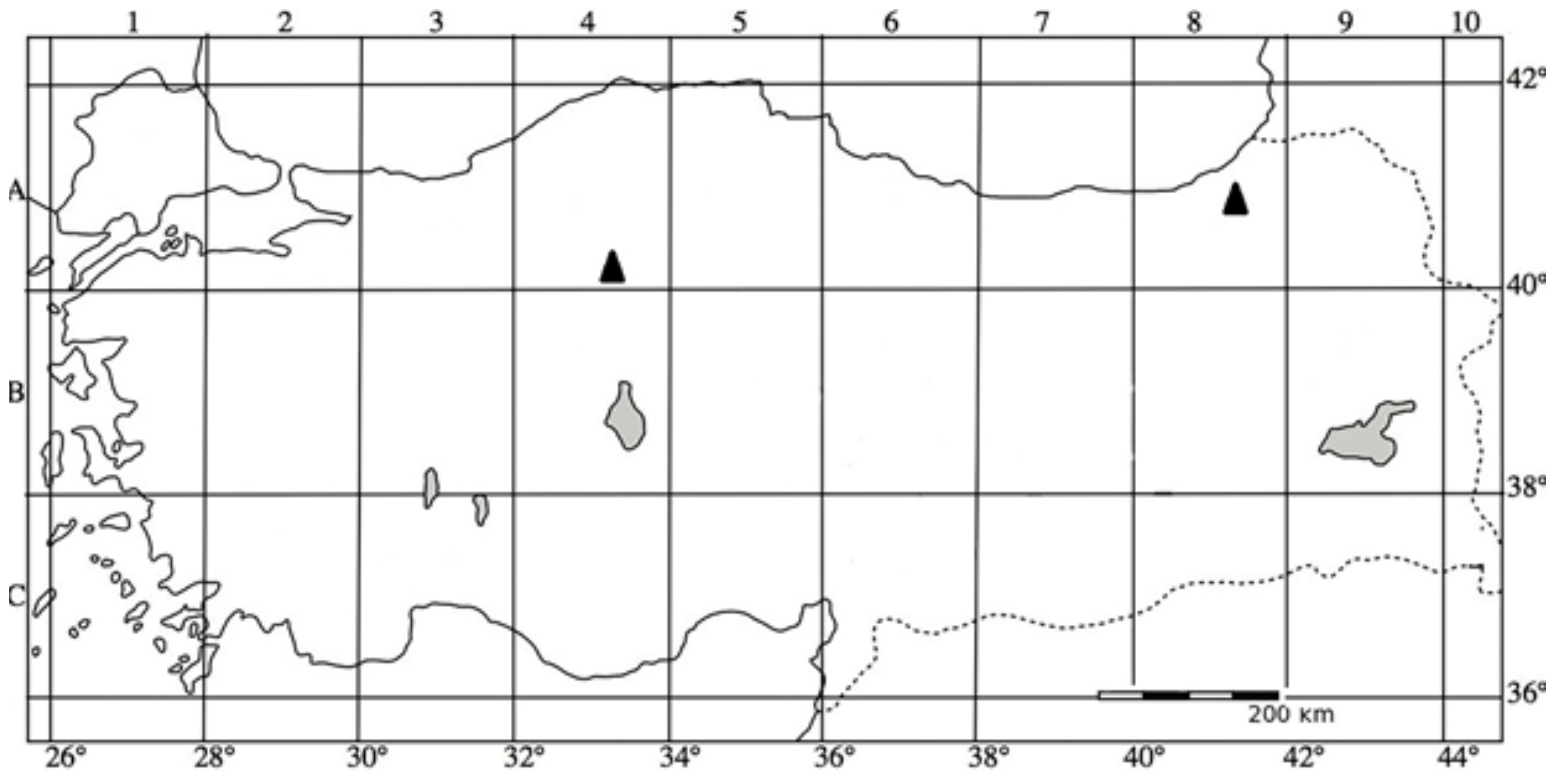

Figure 2. Distribution map of Sorbus buschiana in Turkey $(\Delta)$.

\section{Phenology}

Flowering in May to June. Fruiting in September to October.

\section{Distribution}

Turkey (Figure 2), Caucasia. Euro-Siberian element.

Sorbus Iuristanica (Bornm.) Sch.-Tem. In Rech. Flora Iranica 66: 45. 1969.

The specimens of the species were firstly collected from Iran in 1904 and published on subspecific level by Bornmüller [11]. Same type material was published as specific level by Schönbeck.-
Temesy with a description. Both of the authors didn't include Turkey as a distribution area of $S$. Iuristanica.

The species were first mentioned in the Sorbus account of Turkish flora that naturally grows in Turkey [9]. More comprehensive monographic work of the same author [1] is supported with a picture and distribution map of presence of the species in Turkey. All of the subsequent literatures [5,12], except Aldasoro [4] are accepted presence of the species in Turkey. 


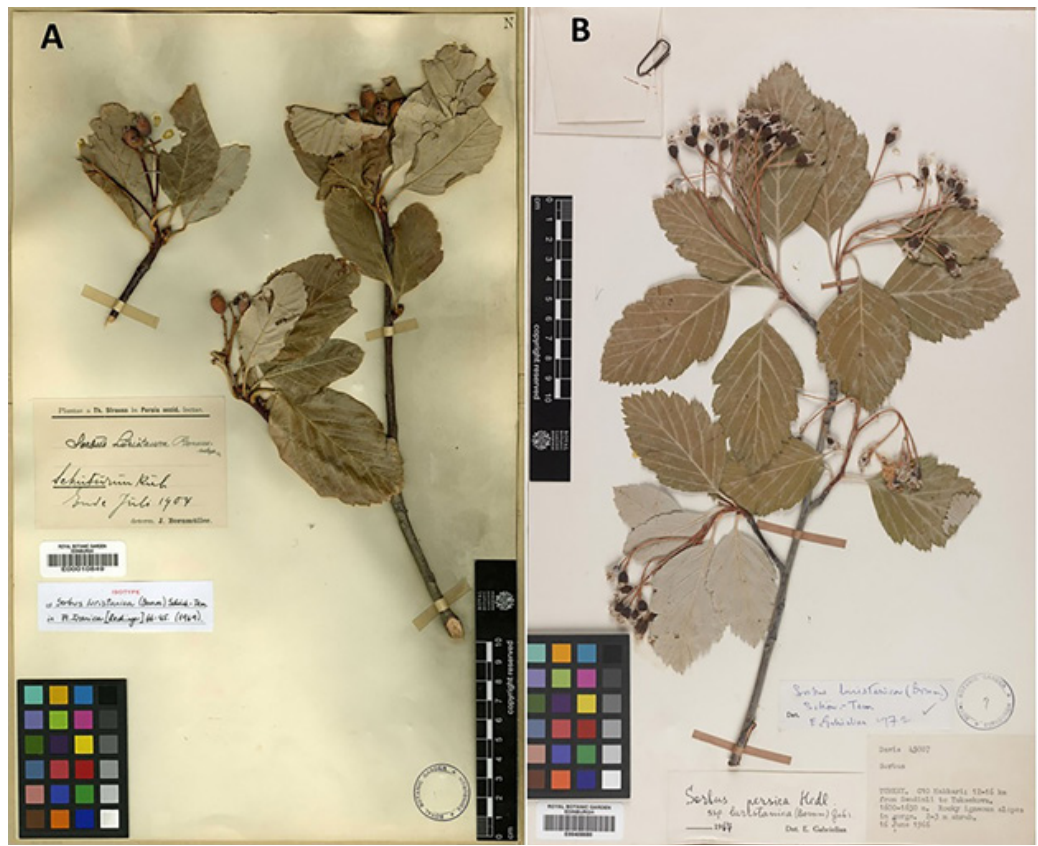

Figure 3. Isotype of S. Iuristanica (A), specimen of P.H.Davis from digital collection of Edinburgh herbarium (B).

The studies on the type material and all of the other materials identified as S. Iuristanica inferred that the species doesn't grow in Turkey. Formerly believe presence of the species in Turkey is attributed to misidentification of the herbarium specimens (P.H.Davis 45007! E herbarium and Rix 41 specimen-herbarium unspecified) by the author of the flora and monograph [1,9]. Moreover, during the field trips to east and southeast part we paid special attention to the species against to possibility of presence in Turkey. Due to extensive field studies, herbarium examinations and misidentification of the previous materials, we acknowledge that S. Iuristanica doesn't grow in Turkey.

Upon comparing the isotype of S. Iuristanica (Figure $3 \mathrm{~A}$ ) and P.H.Davis specimen (Figure 3B), it is clear that both of the specimens are different from each other. Leaf base of S. Iuristanica is nearly entire up to middle and the margin of leaves continues with small dentation. Margin of P.H.Davis sample is lobed and lobes have finely and abundant serrate tooth. Moreover, dentation starts from nearly base to apex. Taking above mentioned characteristics into consideration all of the characters, it is clear that Davis's specimen is clearly belongs to S. persica Hedl.

\section{ACKNOWLEDGEMENTS}

The authors wish to thank TUBITAK (Project No: 111 T 850) for financial support.

\section{References}

1. E.T. Gabrielian, Sorbus in west Asia \& Himalaya. Yerevan: Armenian Academy of Science, (1978) 160165. [In Russian, with English summary].

2. A. Kurtto, Rosaceae (pro parte majore). In: Euro+Med Plantbase - the information resource for EuroMediterranean plant diversity, 2009.

3. I.D. Zinserling, Sorbus buschiana In: Komarov (ed.). Flora Unionis Rerum-publicarum Sovieticarum Socialisticarum, Vol.9:392-495. Leningrad: Academy of Sciences USSR, 1939.

4. J.J. Aldasoro, C. Aedo, F.M. Garmendia, F.P. de la Hoz, C.Navarro, Revision of Sorbus subgenera Aria and Torminaria (Rosaceae-Maloideae). Syst. Bot. Monogr., 69 (2004) 1-148.

5. T. Mataracı, Sorbus L. In: Güner, A., Aslan, S., Ekim, T., Vural, M. \& Babaç., M.T. (eds.). Türkiye Bitkileri Listesi (Damarlı Bitkiler). Nezahat Gökyiğit Botanik Bahçesi ve Flora Araştırmaları Derneği Yayını, İstanbul, 2012.

6. K.R. Robertson, J.B. Phipps, J.R. Rohrer, P.G. Smith, a synopsis of genera in Maloideae (Rosaceae), Syst. Bot., 16 (1991) 376-394.

7. D.J. Mabberley, Sorbus L. Mabberley's Plant Book. Cambridge, 2008.

8. A.A. Dönmez, Z. Uğurlu, S. Işık, Türkiye'deki Pomeae (Rosaceae) Cinslerinin (Crataegus L. hariç) Revizyonu. TÜBiTAK-TBAG, 111 T 850 no'lu Araştırma Projesi, 2015.

9. E.T. Gabrielian, Sorbus L. In: Davis P.H. (ed.). Flora of Turkey and the East Aegean Islands. Vol 4: 147-156. Edinburgh University Press, Edinburgh, 1972. 
10. IUCN (The International Union for Conservation of Nature) 2016. The IUCN Red List of Threatened Species. Version 2016-1. 〈http://www.iucnredlist.org〉. Downloaded on 30 June 2016.
11. J.F.N. Bornmüller, Beih. Bot. Centrbl., 28 (1911) 2-227.

12. TUBiVES 2016. http://www.tubives.com/index.php. Accessed on 30 June 2016. 
